\title{
Recovery Air Rendaman Bumbu Garam dari Industri Kacang Bawang
}

\author{
Recovery Liquid Waste Generated from the Cooking Process in the Bean \\ Industry
}

\author{
Liayati Mahmudah \\ Balai Riset dan Standardisasi Industri Surabaya \\ Kementerian Perindustrian \\ Surabaya, Indonesia \\ lia.mahmudah@yahoo.com
}

\author{
Nurul Mahmida Ariani \\ Balai Riset dan Standardisasi Industri Surabaya \\ Kementerian Perindustrian \\ Surabaya, Indonesia
}

\begin{abstract}
Abstrak- Limbah cair yang dihasilkan dari proses pemasakan di industri kacang bawang memiliki kadar garam ( $\mathrm{NaCl}$ ) cukup tinggi sekitar $\mathbf{2 8 , 9 \%}$ dengan derajat boume sekitar 35 Be, sehingga sulit untuk diolah dalam Instalasi Pengolahan Air Limbah (IPAL) yang sudah ada dan memerlukan biaya yang cukup besar baik dalam instalasi maupun proses pengolahannya. Salah satu cara untuk mengolah air limbah ini adalah dengan mereuse air limbah dengan menambahkan tawas untuk mengendapkan kotoran dalam air limbah sehingga diperoleh air garam yang lebih jernih dan dapat digunakan kembali dalam proses pemasakan, namun kadar Na dalam larutan menjadi turun hingga $51 \%$. Cara lainnya dengan me-recycle air limbah rendaman kacang bawang sehingga diperoleh Kristal garam. Metode yang digunakan adalah proses kristalisasi, penguapan secara alami menggunakan sinar matahari. Secara visual garam yang dihasilkan berwarna hitam pekat karena pengaruh dari kotoran dan sisa tanah yang tercampur dalam air limbah. Garam yang dihasilkan memenuhi syarat mutu hampir disemua parameter sesuai SNI 3556:2010 Garam Konsumsi Beryodium, kecuali kadar $\mathrm{NaCl}$. Kadar $\mathrm{NaCl}$ garam ini hanya $86 \%$ dibawah syarat mutu min $94 \%$. Oleh karena itu dilakukan proses pencucian dengan air brine sampai $3 x$ pencucian sehingga diperoleh kadar $\mathrm{NaCl}$ menjadi 95,9\%.
\end{abstract}

Kata Kunci-kristalisasi, garam konsumsi beryodium, penguapan, SNI 3556:2010, pencucian, air bittern

Abstract-- Liquid waste generated from the cooking process in the onion bean industry has a $28.9 \%$ of salt content ( $\mathrm{NaCl}$ ), and 35 Be of a Baume degree. So it's making difficult to be processed in existing WWTPs and requires substantial costs both in installation and the processing. One way to treat this wastewater is to reuse it by using aluminum sulfate to purify the water, but the Na content in the solution lost up to 51\%. Another way is to recycle garlic soaking wastewater so that the salt crystals are obtained by the natural crystallization process of evaporation using sunlight. Visually the resulting salt is black because of the influence of dirt and residual soil mixed with wastewater. The resulting salt meets the quality requirements in almost all parameters according to SNI 3556: 2010 Iodized Consumption Salt, except $\mathrm{NaCl}$ levels. The salt $\mathrm{NaCl}$ content is only $86 \%$ under the minimum quality requirement of 94\%. Therefore carried out the process of washing with brine water up to $3 x$ washing to obtain levels of NaCl to $95.9 \%$
Keywords: crystallization, iodized salt, evaporation, SNI 3556:2010, washing, bittern water

\section{PENDAHULUAN}

Industrialisasi makanan dalam kemasan berkembang sangat pesat, salah satunya adalah industry kacang bawang. Salah satu industry kacang bawang di Pati, Jawa tengah, dalam hitungan basis perhari, kebutuhan bahan baku kacang yang diproses sekitar 260 ton, dengan tambahan garam sebagai bumbu sekitar : 17 ton dan tawas 57 ton, air bersih $2.880 \mathrm{~m}^{3}$, akan menghasilkan limbah cair sebesar $1.140 \mathrm{~m}^{3}$ dengan kandungan garam cukup tinggi , serta limbah padat endapan tanah sebesar 70 ton.

Limbah cair yg mempunyai kandungan garam dan organiknya cukup tinggi akan merusak lingkungan jika tidak dikelola dengan baik. Namun apabila di masukkan ke dalam IPAL akan menhambat kinerja IPAL itu sendiri dan menghabiskan biaya yang cukup besar karena dalam instalasi peralatannya bahan yang digunakan harus tahan korosi. Untuk limbah padat berupa lumpur/ tanah selama ini proses penanganannya adalah diserahkan pihak ketiga dengan membayar sejumlah biaya. Dengan memanfaatkan kembali (recovery) limbah cair yang mengandung bumbu penggaraman, maka akan berdampak baik bagi lingkungan serta alternatif pemanfaatan kembali garam yg masih terkandung dalam air limbah.

Limbah yang dihasilkan dari proses pengolahan kacang ini yaitu limbah padat dan limbah cair. Untuk limbah cairnya berupa air sisa pencucian kacang basah,air sisa dari pencucian kacang di mesin washing dan limbah cair yang berasal dari proses pemasakan. Sedangkan untuk limbah padatnya berupa lumpur, tali rafia, sak, plastik, kacang yang tercecer dari pembongkaran kacang, cenos, jembros, dan daun- daun kacang.

Dalam proses pemasakan kacang bawang ini ditambahkan garam, dan tawas. Dan hasil samping dari proses pemasakan ini adalah limbah cair yang berwarna hitam keruh dengan kadar garam sekitar 28,9\%. Limbah cair yang berasal dari sisa 
proses pemasakan sementara ini hanya ditampung, belum dilakukan proses pengolahan ke IPAL dikarenakan memiliki kandungan garam yang sangat tinggi, sehingga IPAL yang tersedia tidak mampu memproses air limbah ini.

Garam merupakan istilah umum untuk senyawa kimia bernama Natrium Chlorida $(\mathrm{NaCl})$. Berdasarkan penggunaannya, garam dapat digolongkan menjadi garam proanalisis (p.a), garam industri, dan garam konsumsi. Garam proanalisis adalah garam untuk reagent (tester) pengujian dan analisis di laboratorium, juga untuk keperluan garam farmasetis di industri farmasi. Garam industri yaitu untuk bahan baku industri kimia dan pengeboran minyak, sedangkan garam konsumsi untuk keperluan garam konsumsi dan industri makanan serta garam pengawetan untuk keperluan pengawetan ikan.

Berdasarkan pemanfaatannya, garam dikelompokkan atas dua kelompok yaitu garam konsumsi dan garam industri. Garam konsumsi berdasarkan SNI memiliki kandungan $\mathrm{NaCl}$ minimal 95\%. Untuk garam industri, dibutuhkan kualitas garam yang lebih baik, misalnya pada industri perminyakan, tekstil dan penyamakan kulit memiliki kandungan $\mathrm{NaCl}$ diatas $97,5 \%$, industri chlor alkaline plant dengan $\mathrm{NaCl}$ diatas $98,5 \%$ dan industri pharmaceutical salt (garam farmasi) dengan kadar $\mathrm{NaCl}$ diatas 99,5\% dan impuritis mendekati 0. Garam farmasi ini bisa disebut garam pro analisis (p.a) karena memiliki impurities mendekati $0 .{ }^{[1]}$

Garam dapat diperoleh dengan tiga cara, yaitu melalui penguapan air laut dengan sinar matahari, penambangan batuan garam (rock salt mining) dan dari sumur air garam (brine). Proses produksi garam di Indonesia umumnya menggunakan metode penguapan air laut dengan bantuan sinar matahari. ${ }^{[1]}$. Pembuatan garam secara tradisional ini dilakukan di tambak garam dengan mengunakan air laut kemudian dialirkan ke tambak garam dengan bantuan kincir angin. Dengan memanfaatkan panas sinar matahari maka proses evaporasi akan berlangsung dan terjadi selama beberapa hari, kemudian kristal-kriatal garam akan mulai terbentuk. ${ }^{[2]}$ Produktivitas lahan garam tiap daerah tidak sama, hal ini sangat dipengaruhi oleh kualitas tanah yang tersedia, kelembaban udara, kecepatan angin dan sistem teknologi yang digunakan. Sistem ini secara ilmiah disebut proses kristalisasi.

Kristalisasi dari larutan dikategorikan sebagai salah satu proses pemisahan yang efisien. Secara umum, tujuan dari proses kristalisasi adalah menghasilkan produk kristal dengan kualitas seperti yangdiharapkan. Kualitas kristal yang dihasilkan dapat ditentukan dari parameter-parameter produk yaitu distribusi ukuran kristal), kemurnian kristal dan bentuk kristal. Salah satu syarat terjadinya kiristalisasi adalah terjadinya kondisi supersaturasi.Kondisi supersaturasi adalah kondisi dimana konsentrasi larutan berada diatas harga kelarutannya. Kondisi supersaturasi ini dapat dicapai dengan cara penguapan, pendingin atau gabungan keduanya. Terdapat dua phenomena penting pada proses kristalisasi yaitu pembentukan inti kristal (nukleasi) dan pertumbuhan kristal (crystal growth). ${ }^{[3]}$

Untuk meningkatkan kadar $\mathrm{NaCl}$ dalam garam yang dihasilkan oleh rakyat, perlu dilakukan proses pencucian untuk memurnikan kadar $\mathrm{NaCl}$ dalam garam. ${ }^{[4]}$ Pemurnian garam dilakukan untuk mereduksi pengotor yang terkandung dalam kristal garam, baik pengotor yang terdapat di permukaan kristal maupun pengotor yang terdapat di dalam kisi kristal. Pengotor dalam garam dapat berupa pengotor tak larut, seperti debu, tanah, dan pasir, serta pengotor terlarut yang didominasi oleh $\mathrm{Ca} 2+$ dan $\mathrm{Mg} 2+$. Pengotor yang terdapat dipermukaan kristal dapat direduksi dengan proses pencucian, sedangkan pengotor di dalam kisi kristal dapat direduksi dengan proses pelarutan, pengendapan, dan rekristalisasi. Proses pencucian dapat dilakukan menggunakan air ataupun larutan garam jenuh, namun, pencucian menggunakan air akan ikut melarutkan garam, sehingga pada proses ini $10-40 \%$ garam akan hilang ${ }^{[5]}$. Pengotor yang terdapat didalam kisi kristal umumnya direduksi dengan metode pelarutan dilanjutkan dengan rekristalisasi. Kristal garam dilarutkan dalam air sehingga pengotor terlarut dapat ikut melarut dalam air.Bahan pengikat pengotor dapat ditambahkan untuk mengendapkan $\mathrm{Ca} 2+$ dan $\mathrm{Mg} 2+$.Endapan yang terbentuk dan juga pengotor yang tak larut (debu, tanah, dan pasir) dapat dipisahkan secara filtrasi.

Larutan garam yang telah bersih dari pengotor kemudian dijenuhkan dan diuapkan hingga diperoleh kristal garam yang lebih murni. Proses rekristalisasi ini membutuhkan energi panas yang cukup besar untuk dapat menguapkan semua sisa air dan mengkristalkan kembali garam yang sudah dimurnikan [6]

\section{BAHAN DAN METODE}

Bahan yang digunakan adalah air limbah sisa pemasakan pada industri kacang bawang, dan garam krosok untuk membuat air pencuci.

Alat yang digunakan diantaranya baki untuk proses kristalisasi, boume meter, batang pengaduk, beaker glass dan gelas ukur.

Penelitian ini dilaksanakan di Laboratorium Kimia dan Lingkungan Baristand Industri Surabaya, meliputi beberapa tahap yakni :

\section{A. Karakterisasi bahan air limbah dari proses pemasakan / Lindi}

Air limbah sisa pemasakan kacang bawang diuji secara kimia dilaboratorium untuk melihat kandungan $\mathrm{NaCl}$ dan bahan pengotor lainnya. Pengujian $\mathrm{NaCl}$ dilakukan secara titrimetri untuk mengetahui berapa besar kandungan $\mathrm{NaCl}$ yang masih terkandung dalam air limbah, sehingga masih memungkinkan untuk dilakukan proses recycle ataupun reuse. Untuk mengetahui kadar zat organic dalam air limbah dilakukan pengujian BOD, COD, dan pengujian permanganate $\mathrm{KMnO}_{4}$.

\section{B. Reuse limbah dengan tujuan mendapatkan larutan garam}

Tujuan dari reuse limbah ini untuk mendapatkan larutan garam. Metodologi yang digunakan adalah dengan menggunakan tawas untuk menjernihkan limbah air rendaman kacang bawang. $100 \mathrm{ml}$ air rendaman kacang bawang ditambahkan 5 gr tawas, kemudian dilakukan pengadukan dan didiamkan selama 4 jam sehingga terbentuk endapan didasar 
beaker glass. Endapan dipisahkan, sehingga diperoleh larutan air garam yang bisa digunakan kembali untuk proses pemasakan.

\section{Recovery limbah dengan tujuan mendapatkan kristal garam.}

Melakukan proses kristalisasi air limbah rendaman kacang bawang sehingga terbentuk kristal garam dan dilakukan proses washing. $300 \mathrm{ml}$ air limbah pemasakan diletakkan kedalam wadah denga ukuran $15 \times 20 \mathrm{~cm}$, kemudian dilakukan penjemuran dibawah matahari langsung sampai 4-5 hari sehingga diperoleh Kristal garam. Kristal garam yang diperoleh dilakukan pencucian dengan menggunakan air brine sehingga diperoleh Kristal garam yang lebih putih, kemudian dilakukan penjemuran 1 hari dan diperoleh Kristal garam yang lebih bersih.

\section{Karakterisasi kristal garam yang diperoleh dengan parameter syarat mutu Garam Konsumsi Beryodium SNI 3556:2010}

Kristal garam yang dihasilkan dari pross washing, dilakukan pengujian parameter sesuai syarat mutu SNI 3556:2010 Garam Konsumsi Beryodium yaitu kandungan NaCL, kadar Air, Bagian tidak larut dalam air dan cemaran logam. Cara pengujiannya sesuai dengan SNI 3556:2010. ${ }^{[7]}$

\section{HASIL DAN PEMBAHASAN}

\section{A. Karakterisasi bahan air limbah dari proses pemasakan / Lindi}

Limbah hasil pemasakan industry kacang bawang berwarna hitam pekat seperti yang terlihat dalam gambar 1 . Warna hitam pekat yang terdapat dalam limbah ini berasal dari tanah yang ada dalam kacang tanah.

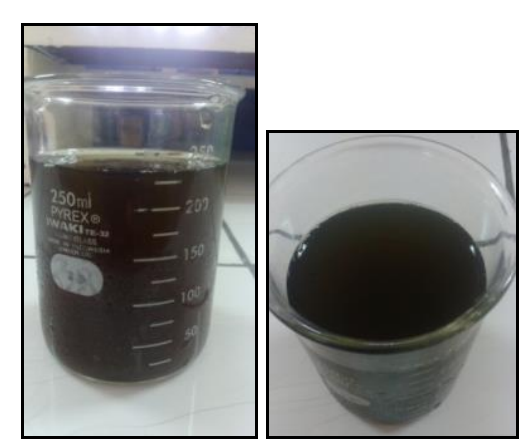

Gambar 1. Limbah pemasakan

Dalam proses pemasakan juga ditambahkan tawas untuk membersihkan kacang dari sisa tanah, sehingga dalam proses karakterisasi juga dicek kadar Al.
TABEL 1. HASIL ANALISA LimbaH CAIR DARI INDUSTRI KACANG BAWANG

\begin{tabular}{ccc}
\hline Parameter & Hasil uji & Satuan \\
\hline Besi (Fe) & 2.8 & $\mathrm{mg} / \mathrm{L}$ \\
\hline $\mathrm{NaCl}$ & 28.09 & $\mathrm{mg} / \mathrm{L}$ \\
\hline $\mathrm{Al}$ & 99.6 & $\%$ \\
\hline $\mathrm{TDS}$ & 27.14 & $\mathrm{mg} / \mathrm{L}$ \\
\hline $\mathrm{TSS}$ & 1580 & $\mathrm{mg} / \mathrm{L}$ \\
\hline Sulfat & 7250 & $\mathrm{o} \mathrm{Be}$ \\
\hline Derajat Boume & 35 & $\mathrm{mg} / \mathrm{L}$ \\
\hline Zat Organik & 11493 & $\mathrm{mg} / \mathrm{L}$ \\
\hline KMnO4) & & $\mathrm{mg} / \mathrm{L}$ \\
\hline BOD & 421.75 & 1750 \\
\hline
\end{tabular}

Jika dilihat dari tabel 1 di atas, kadar organik dalam limbah pemasakan kacang bawang sangat tinggi mencapai 11.493 $\mathrm{mg} / \mathrm{l}$. nilai BOD mencapai $421,75 \mathrm{mg} / \mathrm{l}$. menurut permenLH No. 51 tahun 2004 mengenai baku mutu air laut, baku mutu kandungan BOD dalam air laut maksimal $20 \mathrm{mg} / \mathrm{L}$. Air laut merupakan bahan baku untuk pembuatan garam, sehingga apabila limbah pemasakan ini langsung dibuang ke laut sangat mencemari biota lautan, karena kandungan BOD jauh melebihi baku mutu yang dipersyaratkan.

Parameter BOD Biochemical Oxygen Demand (BOD) merupakan suatu karakteristik yang menunjukkan jumlah oksigen terlarut yang diperlukan oleh mikroorganisme untuk mengurai atau mendekomposisi bahan organik dalam kondisi aerobik. BOD adalah angka indeks untuk tolak ukur pencemar dari limbah yang berada dalam suatu perairan. Makin besar kosentrasi BOD suatu perairan, menunjukan konsentrasi bahan organik di dalam air juga tinggi ${ }^{[8]}$

Kadar $\mathrm{NaCl}$ limbah pemasakan ini mencapai $28.09 \%$ dan derajat boume sekitar $35^{\circ} \mathrm{Be}$. Oleh karena itu jika diolah dalam Instalasi Pengolahan Air limbah (IPAL) yang ada, membutuhkan biaya yang cukup besar dan tidak dapat diolah secara aerob, karena tingginya kadar $\mathrm{NaCl}$ menyebabkan mikroba mati dan menyebabkan instalasi IPAL cepat korosif.

Tahun 2015, Nanik melakukan penelitian pengolahan limbah industri kacang garing dengan metode lumpur aktif. Hasil penelitian ini menunjukkan bahwa terdapat penurunan nilai BOD dan permanganat pada sampel namun tidak terjadi penurunan untuk parameter nilai klorida. Dan juga air limbah hasil pengolahan belum dapat memenuhi baku mutu yang dipersyaratkan dimana nilai BOD $352,2 \mathrm{mg} / \mathrm{L}$, permanganat $213,4 \mathrm{mg} / \mathrm{L}$ dan klorida $8347 \mathrm{mg} / \mathrm{L}$ dan $\mathrm{pH} 8$. ${ }^{[9]}$

\section{B. Reuse limbah dengan tujuan mendapatkan larutan garam}

Jumlah pemakaian air yang digunakan dalam proses pemasakan kacang bawang cukup besar yaitu $2.880 \mathrm{~m} 3 / 260$ ton kacang tanah. Oleh karena itu diharapkan dengan 
penambahan tawas air larutan garam ini bisa digunakan kembali dalam proses pemasakan.

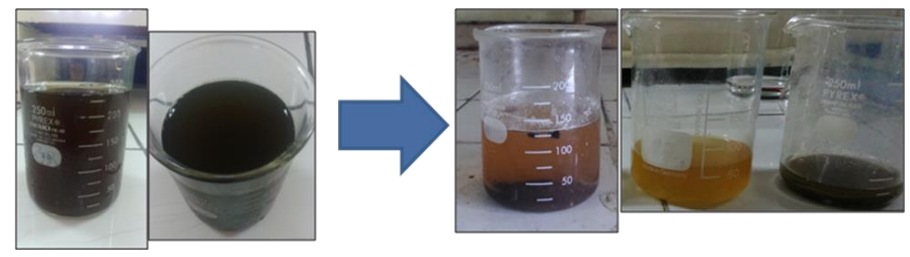

Gambar 2. Penambahan tawas

Gambar 2 Diatas menunjukkan perubahan warna air limbah pemasakan sebelum dan sesudah penambahan tawas. $100 \mathrm{ml}$ air limbah pemasakan ditambahkan tawas padat 2 gram, kemudian diaduk dan dibiarkan sampai terbentuk endapan. Setelah itu endapan dan cairan dipisahkan dan diperoleh filtrate air garam yang lebih jernih. Filtrate yang diperoleh diuji kadar mineral $\mathrm{Na}, \mathrm{Ca}$ dan $\mathrm{Mg}$ dengan hasil seperti dalam table 2 dibawah ini.

Tabel 2. Hasil Analisa Limbah Cair Setelah Penambahan Tawas

\begin{tabular}{ccc}
\hline Parameter & $\begin{array}{c}\text { Air Limbah } \\
\text { Awal }\end{array}$ & $\begin{array}{c}\text { AL setelah } \\
\text { penambahan } \\
\text { tawas }\end{array}$ \\
\hline $\mathrm{Na}(\mathrm{mg} / \mathrm{L})$ & 214.050 & 104.450 \\
\hline $\mathrm{Ca}(\mathrm{mg} / \mathrm{L})$ & 786,11 & 163,79 \\
\hline $\mathrm{Mg}(\mathrm{mg} / \mathrm{L})$ & 3810 & 3113 \\
\hline
\end{tabular}

Dari hasil analisa pada tabel 2. Diperoleh kadar mineral Na dan Ca mengalami penurunan yang cukup signifikan. Kadar mineral $\mathrm{Na}$ dalam larutan garam turun hingga $51 \%$, bahkan $\mathrm{Ca}$ turun hingga 79\%. Hal ini dikarenakan mineral $\mathrm{Na}$ dan $\mathrm{Ca}$ mengalami reaksi dengan tawas dan membentuk endapan. Reaksinya adalah sebagai berikut :

$$
\begin{aligned}
& 6 \mathrm{Na}^{+}+\mathrm{Al}_{2}\left(\mathrm{SO}_{4}\right)_{3} \rightarrow 3 \mathrm{Na}_{2}\left(\mathrm{SO}_{4}\right)+2 \mathrm{Al}(\mathrm{OH})_{3} \\
& 3 \mathrm{Ca}^{2+}+\mathrm{Al}_{2}\left(\mathrm{SO}_{4}\right)_{3} \rightarrow 3 \mathrm{Ca}\left(\mathrm{SO}_{4}\right)+2 \mathrm{Al}(\mathrm{OH})_{3}
\end{aligned}
$$

Sehingga dari rekasi diatas, maka mineral $\mathrm{Na}$ dan $\mathrm{Ca}$ mengalami pengendapan dan penurunan konsentrasinya dalam larutan.

\section{Recovery limbah dengan tujuan mendapatkan kristal garam}

Air limbah perendaman kacang bawang dilakukan proses kristalisasi sehingga terbentuk kristal garam. Proses kristalisasi dilakukan dengan metode penguapan oleh sinar matahari. Proses kristalisasi air limbah pemasakan ini ditunjukkan dalam gambar 3. Dimana Kristal garam yang terbentuk berwarna hitam pekat.

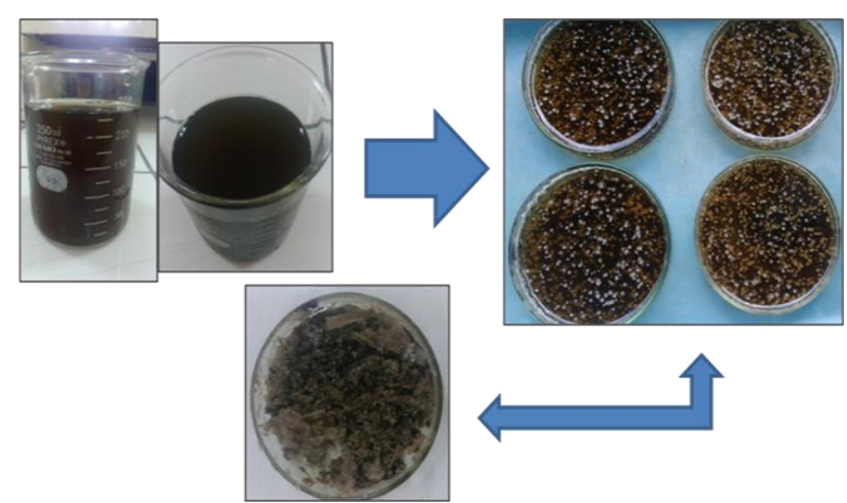

Gambar 3. Proses kristalisasi

Proses kristalisasi dengan penguapan sinar matahri memerlukan waktu sekitar 5 hari tergantung dari ketinggian dan luas permukaan larutan serta porositas nampan. Secara laboratorium proses kristalisasi dilakukan diatas petric disc atau nampan plastik yang tidak memiliki porositas, sehingga proses kristalisasi memakan waktu yang lebih lama, yaitu sekitar 7 hari untuk ketinggian larutan $2 \mathrm{~cm}$. Garam hasil dari proses kristalisasi air limbah rendaman kacang bawang masih berwarna hitam pekat akibat dari endapan tanah yang sisa rendaman kacang tanah.

TABEl 3. HASIL ANALISA Kristal Garam AwaL

\begin{tabular}{ccc}
\hline Parameter & Hasil uji & Syarat Mutu \\
\hline Kadar Air (\%) & 4,7 & Maks. 7 \\
\hline Kadar NaCl (\%) & 86 & Min. 94 \\
\hline $\begin{array}{c}\text { Bag. Tidak Larut } \\
\text { dalam Air (\%) }\end{array}$ & 0,44 & Maks. 0,5 \\
\hline Cemaran Logam : & & Maks. 0,5 \\
\hline Cd (mg/Kg) & $<0,0024$ & Maks 10 \\
\hline Pb (mg/Kg) & 3,8 & Maks. 0,1 \\
\hline Hg (mg/Kg) & 0,08 & Maks. 0,1 \\
\hline As (mg/Kg) & $<0,0008$ & Garam Konsumsi Beryodium
\end{tabular}

Hasil analisa sampel garam hasil dari proses kristalisasi air limbah rendaman kacang bawang dengan parameter sesuai SNI 3556:2010 Garam Konsumsi Beryodium menunjukkan bahwa hamper semua parameter sudah memenuhi syarat mutu kecuali kandungan $\mathrm{NaCl}$ yang masih cukup rendah dibawah $94 \%$ yaitu $86 \%$. Hal ini disebabkan didalam kristal yang terbentuk masih banyak pengotor - pengotor seperti tanah sehingga menyebabkan kristal garam yang terbentuk berwarna hitam pekat dan kadar $\mathrm{NaCl}$ rendah dibawah syarat mutu.

Untuk meningkatkan kadar $\mathrm{NaCl}$ maka dilakukan proses pencucian garam. Garam kotor yang dihasilkan dicuci menggunakan air brine dengan kadar min 24 Be. Untuk menjadikan kristal garam yang berwarna putih maka 
dilakukan 5 tahapan pencucian seperti yang ditunjukkan pada gambar 4 dibawah ini.
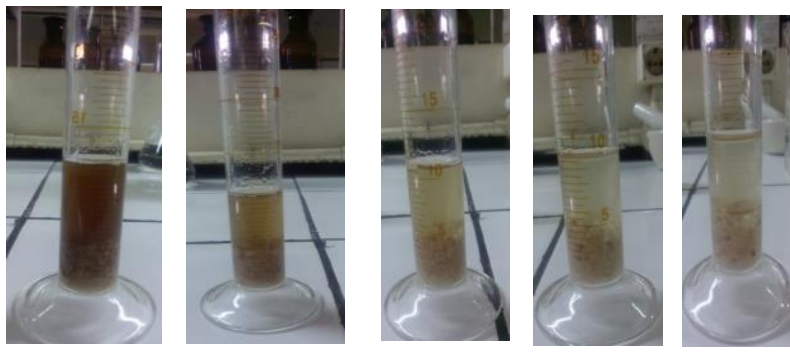

Gambar 4. Proses pencucian garam

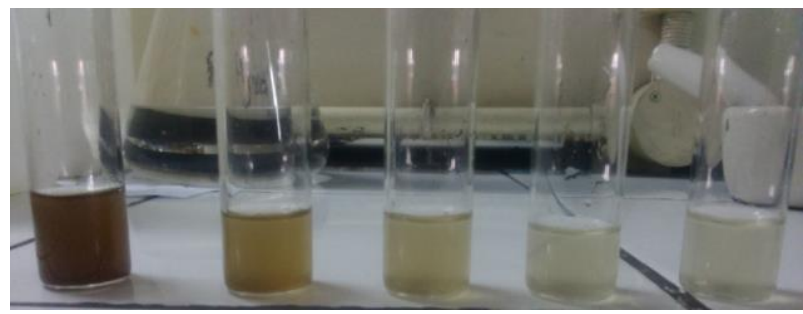

Gambar 5. Air bekas pencucian garam

Dari gambar 4 dan 5 dapat dilihat perbedaan warna yang cukup signifikan air bekas pencucian garam. Pada pencucian pertama air bekas pencucian garam berwarna pekat. Hal ini menunjukkan pengotor dalam kristal garam larut dalam larutan pencuci / air brine. Proses pencucian garam yang baik pada dasarnya mampu meningkatkan kualitas garam, bukan hanya sekedar membersihkan garam dari kotoran lumpur atau tanah , tetapi juga mampu menghilangkan zat-zat pengotor seperti senyawa-senyawa $\mathrm{Mg}, \mathrm{Ca}$ dan kandungan zat pereduksi. Dari hasil penelitian yang dilakukan oleh nelson menunjukkan komposisi $\mathrm{Mg}$ dan zat pereduksi yang terendah masing-masing $0,016 \%$ wt dan 2,65 ppm dicapai pada proses pencucian dengan garam halus dengan menggunakan brine 27 $\%$ wt. ${ }^{[10]}$

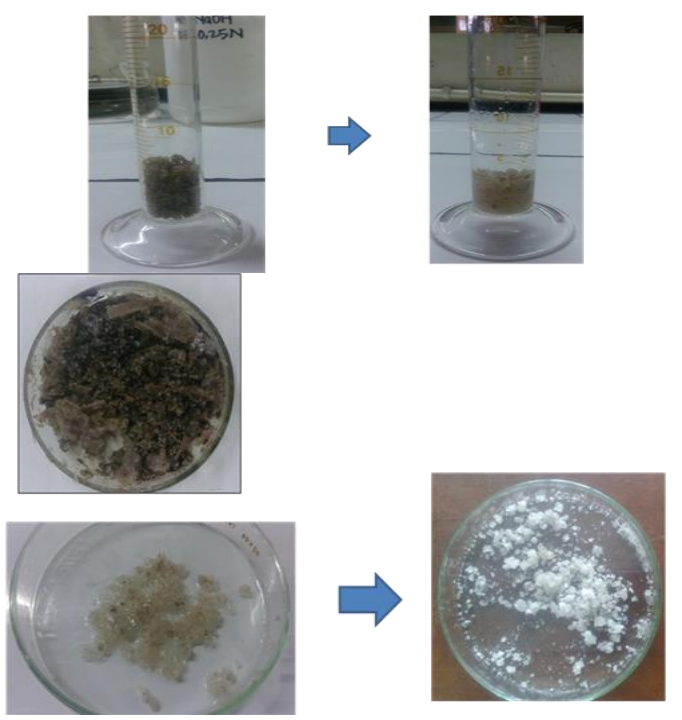

Gambar 6. Hasil akhir kristal garam
Setelah dilakukan proses pencucian dengan air brine dengan 5 kali tahapan pencucian diperoleh kristal garam yang berwarna lebih putih seperti yang ditunjukkan pada gambar 6 diatas. Dengan menggunakan perbandingan berat kristal garam dan berat larutan pencuci 1 : 1 diperoleh kadar $\mathrm{NaCl}$ kristal garam setelah pencucian seperti tabel 4 dibawah ini.

TABel 4. Hasil Analisa Setiap Tahap PEncucian

\begin{tabular}{cc}
\hline Parameter & $\begin{array}{c}\text { Hasil uji } \\
\text { Kadar NaCl (\%) }\end{array}$ \\
\hline Sebelum pencucian & 86 \\
\hline Pencucian I & 93.61 \\
\hline Pencucian II & 93,37 \\
\hline Pencucian III & 95,9 \\
\hline Pencucian IV & 95,64 \\
\hline Pencucian V & 95,79 \\
\hline
\end{tabular}

Dari hasil pada tabel 4 diketahui bahwa pencucian sampai $2 \mathrm{x}$ belum mampu menaikkan kadar $\mathrm{NaCl}$ hingga diatas $94 \%$. Titik optimum untuk pencucian garam kristal air rendaman kacang bawang yaitu pada pencucian ke 3. Artinya pencucian kristal garam yang terbentuk cukup dilakukan 3 kali tahap pencucian, karena kadar $\mathrm{NaCl}$ yang diperoleh sudah di atas syarat mutu SNI Garam Konsumsi Beryodium. Selain itu garam hasil pencucian ke 4 mempunyai kadar $\mathrm{NaCl} 95,64 \%$ sedangkan krital garam hasil pencucian ke 5 mempunyai kadar $\mathrm{NaCl}$ 95,79\%. Dari data tersebut pencucian ke 4 dan ke 5 tidak menunjukkan kenaikan kadar $\mathrm{NaCl}$ yang signifikan. Sehingga pencucian garam cukup dilakukan $3 \mathrm{x}$ tahapan pencucian sehingga dapat mengurangi biaya produksi melalui penghematan pemakaian air brine waktu proses produksi.

\section{KESIMPULAN}

Pengolahan air limbah rendaman kacang bawang yang memiliki kadar $\mathrm{NaCl}$ sebesar $28 \%$ dapat dilakukan dengan melakukan proses kristalisasi sehingga terbentuk kristal garam. Kristal garam yang dihasilkan memenuhi syarat mutu SNI 3556:2010 Garam Konsumsi Beryodium, kecuali kadar $\mathrm{NaCl}$-nya. Untuk menaikkan kadar $\mathrm{NaCl}$ hingga diatas syarat mutu dilakukan proses pencucian dengan air brine $24 \mathrm{Be}$ sampai 3 kali tahapan pencucian sehingga diperoleh kadar $\mathrm{NaCl} 95,9 \%$.

\section{UCAPAN TERIMA KASIH}

Penulis mengucapkan terima kasih kepada Kepala Baristand Industri Surabaya dan Kepala Seksi Teknologi Industri Baristand Industri Surabaya, rekan-rekan tim peneliti, rekan - rekan laboratorium kimia Lingkungan, dewan redaksi majalah dan semua pihak yang telah membantu sehingga penelitian ini dapat terlaksana dan tulisan ini dapat diterbitkan. 


\section{DAFTAR PUSTAKA}

[1]. Yumarta Tansil, Yuyun Belina dan Tri Widjaja, Produksi Garam Farmasi dari Garam Rakyat, JURNAL TEKNIK ITS Vol. 5, No. 2, 2016 ISSN: 2337-3539. Halaman F80-F84

[2]. Cinthia Morris Sartono, Prijadi SOedarsono, Max Rudolf, 2013, Konversi Tonase Air dengan Berat Garam yang Terbentuk di Areal Pertambakan Tanggultlare Jepara. Journal of Management of Aquatic Resources, Vol 2 No. 3, Tahun 2013, Halaman 20-26

[3]. Puguh Setyopratomo, Wahyudi Siswanto dan Heru Sugiyanto Ilham. Studi Eksperimental Pemurnian Garam Nacl Dengan Cara Rekristalisasi. Unitas, Maret 2003 - Agustus 2003, Vol. 11 no.2 hal 17 28

[4]. Ifan R. Suhelmi dan Hariyanto Triwibowo. Pemurnian Garam Sistem Mekanis untuk Menghasilkan Garam Konsumsi Sehat. Ekonomi Biru Sumberdaya Pesisir (ISBN 978-602-9086-40-9/e-ISBN 978-602-908641-6). Hal $32-42$
[5]. Wilarso, D. 1996. Peningkatan Kadar $\mathrm{NaCl}$ pada Proses Pencucian Garam Rakyat di Pabrik.Buletin Penelitian dan Pengembangan Industri.21 : 23-26

[6]. Angela Martina, Judy Retti Witono. Pemurnian Garam Dengan Metode Hidroekstraksi Batch. University Research Colloquium 2015. ISSN 2407-9189. Hal 36-42.

https://publikasiilmiah.ums.ac.id/bitstream/handle/11617/5110/5.pdf;se quence $=1$

[7]. BSN. SNI 3556:2012 Garam Konsumsi Beryodium.

[8]. Yudo, S. 2010. Kondisi kualitas air Sungai Ciliwung di Wilayah DKI Jakarta ditinjau dari parameter organik, amoniak, fosfat, deterjen dan bakteri coli. Jurnal Akuakultur Indonesia, 6(1), 34-42.

[9]. Nanik Indah Setianingsih, Danny Widyakusuma Hermawandan Nilawati. Pengolahan Air Limbah Kadar Garam Tinggi dengan Sistem Lumpur Aktif. Jurnal Riset Teknologi Pencegahan Pencemaran Industri Vol. 6, No. 2, November 2015. Hal $45-50$

[10]. Saksono, 2002, Studi Pengaruh Proses Pencucian Garam Terhadap Komposisi dan Stabilitas Yodium Garam Konsumsi, Makara, Teknologi, Vol.6, No.1, April 2002. 